\title{
Analisis Pemanfaatan e Learning di Masa Pandemi (Studi Kepustakaan: Learning Loss pada Peserta Didik)
}

\author{
Donna Rhamdan ${ }^{1}$, Atrendy Kule ${ }^{2}$, Sucahyo Mas'an Al Wahid ${ }^{3 *}$ \\ 1,2,3 Universitas Borneo Tarakan, Indonesia \\ *email : cahyowahid@borneo.ac.id
}

\begin{abstract}
Learning loss is an educator's concern for students, the loss of learning both cognitively with the achievement of competencies that should be achieved comprehensively but partially achieved. It can also be in the form of loss of motivation to learn, one of the methods used is utilizing e-learning and the development of interesting learning media for students. This study aims to reveal the ways that can be chosen to maximize the benefits of e-learning, considering the development of e-learning is very fast despite the advantages and disadvantages of its use. The research that will be conducted uses qualitative research methods with a literature study approach. The research stages include the type of library, reviewing library materials, and recommendations. The subject of this research is the researcher himself with the help of various types of literature reviews such as books and research articles. The data obtained is in the form of e learning recommendations that can reduce the impact of learning loss. The results of the research based on the literature study show that Learning Loss is found in many countries with reading problems compared to other things that have always been a scourge for subjects outside of literacy and numeracy understanding. Then e-learning can be presented by knowing in advance the needs of students to reduce boredom and perceptions in the use of platforms and applications, then popular e-learning activities in the form of online whiteboards, as well as STAD and PBL learning models that are used in the implementation of e-learning to improve learning outcomes. language skill.
\end{abstract}

\section{Keywords: Literature Study, Learning Loss, E Learning}

\begin{abstract}
Abstrak: Learning loss merupakan kekhawatiran pendidik terhadap peserta didik, hilangan pembelajaran baik secara kognitif dengan pecapaian kompetensi yang seharusnya tercapai menyeluruh akan tetapi tercapai sebagian. Dapat juga berupa kehilangan motivasi belajar, salah satu cara yang digunakan memanfaatkan e learning dan pengembangan media pembelajaran yang menarik bagi peserta didik. Penelitian ini bertujuan untuk mengungkapkan cara-cara yang dapat dipilih untuk memaksimalkan manfaat e learning, mengingat perkembangan e learning sangat cepat meskipun terdapat kelebihan dan kelemahan penggunaannya. Penelitian yang akan dilakukan menggunakan metode penelitian kualitatif pendekatan studi kepustakaan. Tahapan penelitian meliputi jenis pustaka, mengkaji bahan pustaka, dan rekomendasi . Subjek penelitian ini adalah peneliti sendiri dengan berbantuan berbagai jenis kajian pustaka seperti buku dan artikel penelitian. Data yang diperoleh berupa hasil rekomendasi e learning yang mampu mengurangi dampak learning loss. Hasil penelitian berdasarkan studi pustaka bahwa Learning Loss banyak ditemukan diberbagai negara dengan permasalahan kemampuan membaca dibandingkan hal lain yang selalu ini menjadi momok untuk mata pelajaran di luar pemahaman literasi dan numerasi. Kemudian e-learning dapat dihadirkan dengan mengetahui terlebih dahulu kebutuhan siswa untuk mengurangi kejenuhan dan persepsi dalam penggunaan platform dan aplikasi, kemudian kegiatan e-learning yang digemari berupa papan tulis online, serta model pembelajaran STAD dan PBL yang dimanfaatkan dalam pelaksanaan e-learning untuk meningkatakan kemampuan bahasa.
\end{abstract}


Kata Kunci: Studi Kepustakaan, Learning Loss , E Learning

Copyright (c) 2021 The Authors. This is an open access article under the CC BY-SA 4.0 license (https://creativecommons.org/licenses/by-sa/4.0/)

\section{PENDAHULUAN}

Pandemi COVID-19 merubah keseluruhan proses pembelajaran yang ada di dalam kelas. Pemerintah mulai melakukan berbagai tindakan untuk mencegah penularan coronavirus dengan pelaksanaan pembatasan sosial (social distancing) dan penjagaan jarak (physical distancing). Keputusan tersebut berdampak pada sistem pendidikan di Indonesia baik pendidikan dasar, menengah maupun pendidikan tinggi, dimana melalui Surat Edaran Kementerian Pendidikan dan Kebudayaan dilakukan perubahan dalam pelaksanaan proses pembelajaran. Upaya yang dilakukan adalah merubah seluruh proses pembelajaran dalam mode dalam jaringan (daring) penuh atau full online.

Perubahan pembelajaran tatap muka atau blended learning menjadi bentuk daring penuh atau full online tentunya akan berdampak terhadap pencapaian tujuan pembelajaran. (Aziz et al., 2019)menyatakan bahwa penggunaan daring belum tentu cocok pada semua jenis materi pembelajaran, sehingga pembelajaran moda daring akan berdampak terhadap pencapaian tujuan pembelajaran.

Pembelajaran moda daring dapat menjadi pedang bermata dua, bisa bermanfaat kepada pendidik dan peserta didik, maupun sebaliknya. (Alqahtani \& Rajkhan, 2020)menyatakan bahwa pembelajaran moda daring penuh bisa bersifat sinkron atau asinkron jika ditinjau berdasarkan waktu interaksi antara pendidik dan peserta didik. Dia menyatakan sifat sinkron memungkinkan pendidik dan peserta didik berinteraksi secara langsung di saat yang bersamaan melalui konferensi video atau ruang chatting. Sementara itu, sifat asinkron terjadi ketika pendidik dan peserta didik melakukan pembelajaran dengan waktu yang berbeda misalkan pendidik menggunakan video rekaman.

(Almaiah et al., 2020)menyatakan bahwa feedback yang diterima antara sinkron daring bersifat langsung, sementara asinkron daring sifatnya tidak langsung. Namun mereka menambahkan pembelajaran dari yang bersifat sinkron banyak merugikan pada daerah yang minim fasilitas karena terkadang koneksi internet yang buruk atau sarana prasarana yang kurang memadai. Di lain sisi, pembelajaran dari yang bersifat asinkron cenderung menguntungkan karena bisa diakses pada waktu yang sesuai dengan 
kebutuhan peserta didik, namun akan sulit bagi pendidik memberikan feedback pada saat itu juga karena perbedaan waktu.

Pembelajaran daring secara keseluruhan bukan pembelajaran yang sempurna. (Ebner et al., 2020)berpendapat bahwa materi secara online hanya meningkatkan hasil belajar pada bentuk tertentu saja.(Mayer, 2020)juga menyatakan pembelajaran daring hanyalah perangkat pendukung untuk suatu metode tertentu. Bahkan beberapa penelitian menyatakan bahwa pembelajaran daring menghilangkan "interaksi pribadi yang vital" tidak hanya antara pendidik dan peserta didik, tetapi juga diantara masingmasing peserta didik (Pham et al., 2019), kemudian (Al-Fraihat et al., 2020)menambahkan bahwa dampak paling serius dari pembelajaran daring adalah peserta didik mengalami kontemplasi, keterpencilan, serta kurangnya interaksi atau hubungan. Hal ini terjadi karena klarifikasi, penawaran penjelasan, serta interpretasi dari dosen sangat minim.

Dalam dunia pendidikan saat ini mengalami kehawatiran kehilangan pembelajaran (learning loss)karena berjalan satu tahun musibah pandemi ini membuat aktivitas pembelajaran dilakukan secara online, namun dibuktikan terlebih dahulu melalui studi pustaka pada saat semester ini akan komepetensi yang tercapai pada peserta didik ketika pemerintah menindaklanjuti untuk pembelajaran kembali secara tatap muka.

Mengacu pada latar belakang diatas maka tujuan dan urgensi penelitian ini yaitu untuk melakukan tindakan studi kepustakaan kepada peserta didik terkait selama pembelajaran daring dan kompetensi yang seharusnya tercapai, sehingga nantinya ditemukan data otentik bahwa kekhawatiran kehilangan pembelajaran masa pandemi menggunakan platform e learning hanya sebagian kecil peserta didik dan kompetensi pada mata pelajaran tertentu.

\section{METODE Jenis Penelitian}

Penelitian menggunakan pendekatan kualitatif dengan jenis penelitian studi kepustakaan. Penelitian kepustakaan merupakan suatu jenis penelitian yang digunakan dalam pengumpulan informasi dan data secara mendalam melalui literatur, buku catatan, majalah, referensi lainnya, serta hasil penelitian sebelumnya yang relevan, untuk mendapatkan jawaban dan landasan teori mengenai masalah yang diteliti. Sumber data dalam penelitian kepustakaan yaitu data primer dan sekunder, 
pengumpulan data melalui dokumentasi seperti foto, video, USB dll. Analisis data dapat menyesuaikan dengan tujuan penelitian tahapannya deduktif, induktif, interpretatif, komparatif, historis. Instrumen penelitian yaitu peneliti sendiri (human instrumen).
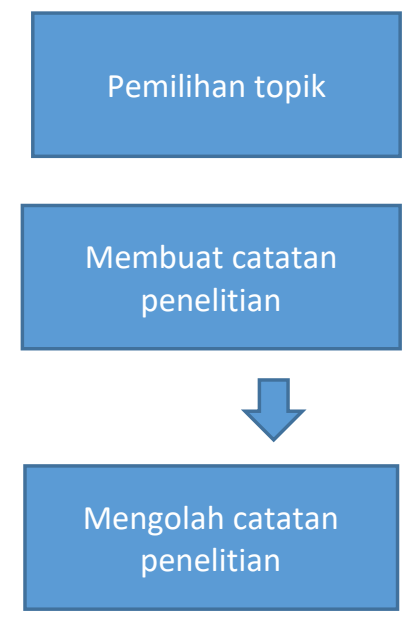

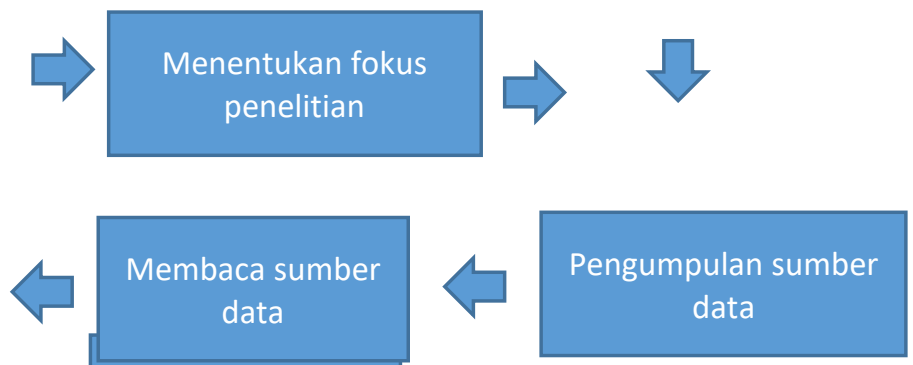

Eksplorasi

informasi

Penyusunan

laporan

Gambar 1. prosedur studi kepustakaan

\section{Instrumen pengumpulan data}

Dalam penelitian ini terdapat setidaknya 5 instrumen pengumpulan data untuk mendapatkan data secara menyeluruh dari sudut pandang peserta didik dan observer. Instrumen yang digunakan antara lain:

a. Mencari sumber data terkait loss learning

b. Menganalisis hasil dari sumber data

c. Mereduksi data

d. Memberikan rekomendasi tentang penggunaan e learning dalam mengurangi dampak learning loss

\section{Analisis Data}

Data analisis dapat dilakukan dengan cara berikut: (1) deduktif yaitu pemikiran yang bertolak pada fakta-fakta yang umum kemudian ditarik pada suatu kesimpulan yang bersifat khusus; (2) induktif yaitu mengambil suatu konklusi atau kesimpulan dari situasi yang kongkrit menuju pada hal-hal yang abstrak ; (3) interpretatif yaitu menginterprestasikan suatu makna menjadi normatif ; (4) komparatif yaitu membandingkan objek penelitian dengan konsep pembanding ; (5) historis merupakan 
analisis kejadian-kejadian di masa yang lalu untuk mengetahui kenapa dan bagaimana suatu peristiwa itu terjadi.

Dari pemaparan data akan diperoleh rekomendasi berdasarkan historis dalam bentuk yang singkat kalimat tetapi memiliki arti luas. Dari hasil rekomendasi juga digunakan untuk menguji kebenaran dan mencocokkan makna data yang diperoleh.

\section{HASIL DAN PEMBAHASAN}

Pembelajaran yang dilaksanakan selama masa pandemi lebih tepatnya belajar dari rumah dengan menggunakan berbagai platform dan aplikasi pembelajaran, agar tujuan pembelajaran tercapai sesuai materi yang disampaikan.Berikut tabel hasil penelusuran penggunaan ruang pembelajaran.

\section{Hasil}

\begin{tabular}{|c|c|c|}
\hline \multicolumn{3}{|c|}{ Tabel 1. Penggunaan E Learning } \\
\hline Nama Peneliti & Judul Penelitian & Rekomendasi \\
\hline Kaffenberger & $\begin{array}{l}\text { Modelling the long-run } \\
\text { learning impact of the } \\
\text { Covid-19 learning shock: } \\
\text { Actions to (more than) } \\
\text { mitigate loss. In } \\
\text { International Journal of } \\
\text { Educational Development. }\end{array}$ & $\begin{array}{l}\text { Fungsi aplikasi dan platform } \\
\text { untuk meningkatkan } \\
\text { kemampuan pedagogis } \\
\text { kepada peserta didik di masa } \\
\text { pembelajaran tatap maya. }\end{array}$ \\
\hline Sabates & $\begin{array}{l}\text { Using educational } \\
\text { transitions to estimate } \\
\text { learning loss due to COVID- } \\
19 \text { school closures: The case } \\
\text { of Complementary Basic } \\
\text { Education in Ghana. } \\
\text { International Journal of } \\
\text { Educational }\end{array}$ & $\begin{array}{l}\text { Pemberian pembelajaran } \\
\text { menggunakan gentika } \\
\text { modern yaitu mengikuti } \\
\text { kegiatan yang dilakukan } \\
\text { pada peserta didik misalnya } \\
\text { pembelajaran dengan tipe } \\
\text { mabar (main bareng) }\end{array}$ \\
\hline Todd & $\begin{array}{l}\text { The Learning Loss Effect in } \\
\text { Genetics: What Ideas Do } \\
\text { Students Retain or Lose } \\
\text { after Instruction? CBE-Life } \\
\text { Sciences Education. }\end{array}$ & $\begin{array}{l}\text { Mengembalikan } \\
\text { keterampilan peserta didik } \\
\text { melalui e-learning audio } \\
\text { visual }\end{array}$ \\
\hline Abbasi & $\begin{array}{l}\text { Perceptions of students } \\
\text { regarding E-learning during } \\
\text { Covid-19 at a private } \\
\text { medical college. In Pakistan } \\
\text { Journal of Medical }\end{array}$ & $\begin{array}{l}\text { 77\% siswa memiliki } \\
\text { persepsi negatif terhadap e- } \\
\text { learning. } 76 \% \text { siswa } \\
\text { menggunakan perangkat } \\
\text { seluler untuk e-learning } \\
\text { mereka. Dapat ditarik } \\
\text { kesimpulan bahwa, Siswa } \\
\text { tidak lebih memilih e- } \\
\text { teaching daripada } \\
\text { pengajaran tatap muka } \\
\text { selama situasi lockdown. }\end{array}$ \\
\hline Almaiah & $\begin{array}{l}\text { E-learning Foundations and } \\
\text { Applications }\end{array}$ & $\begin{array}{l}\text { Blackboard memiliki } \\
\text { beberapa fitur fantastis yang }\end{array}$ \\
\hline
\end{tabular}




\begin{tabular}{|c|c|c|}
\hline & & $\begin{array}{l}\text { akan berguna untuk } \\
\text { digunakan selama COVID- } \\
19\end{array}$ \\
\hline Syakur & $\begin{array}{l}\text { The Effectiveness of } \\
\text { Coopertative Learning } \\
\text { (STAD and PBL type) on E- } \\
\text { learning Sustainable } \\
\text { Development in Higher } \\
\text { Education. Journal of } \\
\text { Development Research. }\end{array}$ & $\begin{array}{l}\text { model pembelajaran inovatif } \\
\text { berbasis Cooperative } \\
\text { Learning Type Student } \\
\text { Teams-Achievement } \\
\text { Division (STAD) dan } \\
\text { Project Based Learning } \\
\text { (PBL). Hasil pengembangan } \\
\text { dan penerapan inovasi } \\
\text { teknologi pendidikan } \\
\text { berbasis e-learning STAD } \\
\text { dan PBL dapat berpengaruh } \\
\text { signifikan terhadap hasil } \\
\text { nilai TOEFL yang mencapai } \\
\text { nilai maksimal 90\% }\end{array}$ \\
\hline Nursalam, $\mathbf{N}$ & $\begin{array}{l}\text { Pemanfaatan Fasilitas } \\
\text { Belajar Di Sekolah Dan } \\
\text { Pengaruhnya Terhadap Hasil } \\
\text { Belajar Ips Siswa Kelas VIII } \\
\text { Mts Darul Falah Cermee } \\
\text { Bondowoso Semester } \\
\text { Genap. }\end{array}$ & $\begin{array}{l}\text { Fasilitas sekolah dapat } \\
\text { memberikan dukungan } \\
\text { terhadap kemampuan peseta } \\
\text { didik dalam mengeksplorasi } \\
\text { kegiatan pembelajaran } \\
\text { secara menyeluruh }\end{array}$ \\
\hline
\end{tabular}

\section{Pembahasan}

\section{A. Pembelajaran yang hilang (Learning Loss)}

Beberapa kejadian pandemi melibatkan permasalahan khususnya pendidikan di berbagai negara, salah satu pendapat seperti yang diungkapkan oleh (Angrist, 2021) Kami memodelkan kerugian pembelajaran akibat pandemi COVID-19 dan pemilihan strategi untuk membangun ketercapaian kembali dengan lebih baik.Data dari Penilaian Membaca Kelas Awal di Etiopia, Kenya, Liberia, Tanzania, dan Uganda menunjukkan hilangnya pembelajaran setengah hingga lebih dari satu tahun.Sependapat dengan pernyataan (Bowers, 2018) Di antara tantangan akademik yang dihadapi oleh siswa dari rumah dengan status sosial ekonomi rendah (SES) adalah hilangnya keterampilan akademik selama bulan-bulan musim panas.Sebanyak 22 siswa SD dari rumah dengan SES rendah berpartisipasi dalam program musim panas yang dirancang untuk meningkatkan kemampuan lisan.Betapa pentingnya pembelajaran secara tatap muka yang semestinya ada pendekatan kompetensi yang hilang saat pembelajaran secara tatap maya baik dirasakan langsung oleh guru ataupun siswa. 
Pandemi COVID-19 telah menutup sekolah untuk lebih dari 1,6 miliar anak, dengan potensi konsekuensi jangka panjang. strategi untuk meminimalkan dampak pandemi pada hasil pendidikan sementara dilakukan dengan moda daring (Angrist N. B., 2020). Kemudian Banyak pendidik bertanya-tanya apa dampak penutupan dan gangguan sekolah terkait COVID-19 terhadap pembelajaran siswa. Menggunakan data kohort dari tahun sebelumnya, kami mengambil skor dari penilaian FastBridge aReading, aMath, dan CBMreading untuk memperkirakan bahwa benar signifikansi pembelajaran tatap maya mengalami penurunan persepsi khususnya pada hasil tujuan pembelajaran (Bielinski, 2020). Berbeda pendapat oleh (Blaskó, 2021) menyatakan bahwa pandemi secara luas berdampak pada ketidaksetaraan pendidikan di seluruh dunia.Namun, berbeda dengan data kesehatan atau pengangguran, data hasil pendidikan tidak tepat.Oleh karena itu, kami memiliki pengetahuan yang sangat terbatas tentang dampak sebenarnya yang terjadi nyata terjadi pada kesehatan dan pengangguran namun untuk pendidikan sebatas kurang memahami penggunaan platform atau aplikasi pembelajaran serta kesiapan fasilitas.

Dapat disimpulkan bahwa dampak pembelajaran daring karena situasi pandemi begitu banyak pandangan guru pembelajar khususnya kegiatan proses belajar mengajar yang menginginkan terlaksananya tujuan yang akan diajarkan dengan mengenal berbagai platform dan aplikasi sebagai kemampuan kinerja guru. Kesimpulan ini juga ditanggapi serius oleh (Engzella, 2021) Penangguhan pengajaran tatap muka di sekolah selama pandemi COVID-19 telah menyebabkan kekhawatiran tentang konsekuensi bagi pembelajaran siswa.Sejauh ini, data untuk mempelajari pertanyaan ini terbatas.Di sini kami mengevaluasi pengaruh penutupan sekolah terhadap kinerja sekolah dasar.

\section{B. Ruang belajar online (E Learning)}

Pada kegiatan proses pembelajaran, beberapa penulis dalam jurnal telah mendapatkan hasil pembelajaran masa pandemi dengan berbagai paltform dan aplikasi yaitu pendapat dari (Kaffenberger, 2021) menggunakan model "fungsi produksi pedagogis" yang dikalibrasi untuk memperkirakan potensi kerugian jangka panjang pada pembelajaran anak-anak dari guncangan sementara penutupan sekolah terkait Covid-19. Ini kemudian memodelkan keuntungan dari dua strategi mitigasi yang diwacanakan. Kemudian pendapat (Kraft, 2017) Perbedaan besar dalam kegiatan belajar musim panas di antara anak-anak menghadirkan tantangan besar untuk 
memberikan kesempatan pendidikan yang sama di Amerika Serikat. Sebagian besar inisiatif yang ditujukan untuk membalikkan kehilangan pembelajaran musim panas berfokus pada program berbasis sekolah atau pusat. Kehilangan belajar diperkirakan terjadi pada jutaan anak yang putus sekolah akibat pandemi COVID-19 saat ini. Sayangnya, tidak pasti berapa banyak pembelajaran yang akan hilang dan seberapa lebar kesenjangan bagi anak-anak yang kurang beruntung dalam mendapatkan pembelajaran secara daring dikarenakan keterbatasan fasilitas menurut (Sabates, 2021). Genetika modern adalah domain yang relatif baru, tetapi semakin penting bagi siswa untuk memiliki pemahaman yang kuat tentang konten, karena teknologi genetik menjadi lebih umum. Dalam studi sebelumnya, kami menggunakan Penilaian Berbasis Kemajuan Pembelajaran berdasarkan temuan dari (Todd, 2018) bahwa pembelajaran dengan konten audio visual dapat menunjang perbaikan pembelajaran. Pendapat yang sama oleh (Travis, 2019) Tantangan yang dihadapi oleh banyak siswa adalah hilangnya keterampilan akademik selama bulan-bulan musim panas. Namun, kurang perhatian diberikan pada kebutuhan sosial dan emosional selama musim panas. Tiga puluh lima siswa sekolah menengah dari rumah SES rendah berpartisipasi dalam musim panas meskipun pelaksanaan pembelajaran daring dikelola oleh guru sesuai kebutuhan siswa. Namun berbeda pendapat dengan $(\mathrm{Xu}, 2017)$ Ada minat yang meningkat untuk mempercepat jaringan saraf untuk aplikasi waktu nyata. Kami mempelajari strategi siswa-guru, di mana jaringan siswa yang kecil dan cepat dilatih dengan informasi tambahan yang dipelajari dari jaringan guru yang besar dan akurat sebelum pandemi melanda. Dapat ditarik kesimpulan bahwa Learning Loss banyak ditemukan diberbagai negara dengan permasalahan kemampuan membaca dibandingkan hal lain yang selalu ini menjadi momok untuk mata pelajaran di luar pemahaman literasi dan numerasi.

Berdasarkan pendapat (Abbasi, 2020) Secara keseluruhan, 77\% siswa memiliki persepsi negatif terhadap e-learning. $76 \%$ siswa menggunakan perangkat seluler untuk e-learning mereka. Dapat ditarik kesimpulan bahwa, Siswa tidak lebih memilih eteaching daripada pengajaran tatap muka selama situasi lockdown. Administrasi dan anggota fakultas harus mengambil langkah-langkah yang diperlukan untuk meningkatkan e-teaching untuk pembelajaran yang lebih baik selama lockdown. Membandingkan sarana faktor mengungkapkan bahwa tantangan yang paling penting bagi siswa untuk belajar online adalah masalah aksesibilitas. Disusul isu sosial, isu 
dosen, isu akademik, dan isu generik. Rata-rata untuk item individual dalam niat siswa untuk belajar online menunjukkan bahwa siswa belum siap untuk belajar online. Analisis Regresi Berganda lebih lanjut dilakukan untuk menentukan faktor mana yang menimbulkan tantangan paling penting bagi keputusan siswa untuk belajar online. Isu sosial dan isu dosen cukup signifikan. Pada model terakhir, hanya masalah dosen yang signifikan. Sebuah pendekatan campuran di mana pengajaran konvensional dikombinasikan dengan pengajaran online seharusnya mengantar peserta didik untuk menyelesaikan pembelajaran online berdasarkan pendapat (Aboagye, 2021). Menurut (Almaiah, 2020) Penyediaan dan penggunaan sistem online dan e-learning menjadi tantangan utama bagi banyak perguruan tinggi selama pandemi COVID-19. Sistem elearning seperti Blackboard memiliki beberapa fitur fantastis yang akan berguna untuk digunakan selama COVID-19. Selama pandemi COVID-19, institusi pendidikan ditutup di seluruh dunia, yang berdampak pada lebih dari 60\% siswa dan menyebabkan gangguan besar pada sistem pendidikan. Berdasarkan informasi dari (Alqahtani, 2020) bahwa data diperoleh dengan mewawancarai 69 pengelola E-learning di lembaga pendidikan selama COVID-19 berdasarkan kriteria evaluasi yang ditetapkan dan pendekatan E-learning melalui beberapa saluran. Kami menemukan bahwa manajemen teknologi, dukungan dari manajemen, peningkatan kesadaran siswa untuk menggunakan sistem E-learning, dan tuntutan teknologi informasi tingkat tinggi dari instruktur, mahasiswa, dan universitas adalah faktor yang paling berpengaruh untuk Elearning selama COVID-19. Di antara kelima sistem pembelajaran tersebut, blended learning merupakan sistem pembelajaran yang paling cocok untuk dipraktikkan. Hasil tersebut menunjukkan bahwa, betapapun luar biasanya teknologi di sebuah institusi pendidikan, kesiapan pelaksanaan E-learning berperan besar dalam mendongkrak proses pendidikan di masa pandemi COVID-19.

Dengan kemajuan teknologi modern, manfaat alat pembelajaran interaktif tidak hanya tersedia untuk sesi di dalam kelas tetapi juga dapat disampaikan melalui internet. Alat seperti berbagi desktop perangkat lunak dapat digunakan untuk mencapai yang sama efektif sesi konferensi web sebagai pemain tunggal. Oleh karena itu, ratusan alat pendidikan digital telah dibuat dengan tujuan memberikan otonomi kepada siswa, meningkatkan administrasi proses akademik, mendorong kolaborasi, dan memfasilitasi komunikasi antara guru dan peserta didik. Penelitian ini dapat bermanfaat bagi banyak 
orang di masa depan, dan upaya harus diperpanjang dengan mereplikasi penelitian dan disarankan dalam penelitian masa depan di mana mereka dapat dilakukan dengan berfokus pada model studi yang sama melalui pengaturan yang berbeda, seperti: menyoroti pendidikan tinggi di satu negara dan bukan seluruh negara. Selanjutnya, studi akan lebih menarik jika penelitian dilakukan melalui cara yang berbeda pendekatan metode pengumpulan data dengan menerapkan pendekatan kualitatif. Ini bisa memungkinkan peneliti untuk mendapatkan lebih banyak informasi atau masukan melalui metode kualitatif, sebagai tanggapan dari responden akan berbeda satu sama lain. Terbukti, seluruh hipotesis penelitian ini telah didukung dan empat faktor yang menyebabkan efektivitas Penggunaan E-Learning dalam sistem belajar mengajar di kalangan siswa telah diidentifikasi. Berdasarkan model, metode yang digunakan dalam penelitian ini dapat mengevaluasi efektivitas Penggunaan E-Learning di kalangan mahasiswa perguruan tinggi. Penelitian ini telah berjalan menuju peningkatan pemahaman kita dalam memanfaatkan E-Learning sebagai alat bantu dalam mengajar dan pendekatan pembelajaran, khususnya di perguruan tinggi sistem. Dengan demikian, penelitian ini diyakini dapat membantu institusi untuk meningkatkan pendekatan mereka dalam pengajaran dan pembelajaran karena akan membantu siswa untuk mengakses e-learning lebih mudah di masa depan. Para siswa lebih memilih untuk memiliki pembelajaran online ketika institusi yang lebih tinggi menyediakan fasilitas yang sangat baik untuk mereka. E-Learning telah benar-benar mengubah cara belajar disampaikan kepada siswa. Tidak seperti papan tulis tradisional dan metode papan tulis, E-Learning membuat belajar lebih mudah, lebih banyak nyaman, dan lebih efektif. Dengan demikian, penelitian ini telah mencapai tujuan dan menemukan temuan baru tentang efek keterampilan TIK - manajemen waktu, sumber daya dan teknik pembelajaran, pada efektivitas perangkat e-learning dalam pendekatan belajar mengajar, antara lain: mahasiswa pendidikan tinggi (Aziz, 2019). Pengembangan dan penerapan teknologi pendidikan di perguruan tinggi dengan model pembelajaran inovatif berbasis Cooperative Learning Type Student Teams-Achievement Division (STAD) dan Project Based Learning (PBL). Hasil pengembangan dan penerapan inovasi teknologi pendidikan berbasis e-learning STAD dan PBL dapat berpengaruh signifikan terhadap hasil nilai TOEFL siswa yang dikemukakan oleh (Syakur, 2020). E-Learning telah menjadi lebih dan lebih populer dalam beberapa tahun terakhir dengan 
kemajuan teknologi baru. Dengan menggunakan perangkat seluler mereka, orang dapat memperluas pengetahuan mereka kapan saja dan di mana saja. E-Learning juga memungkinkan orang untuk mengelola pembelajaran mereka $(\mathrm{Wu}, 2020)$.

Menemukan dari keseluruhan makalah penelitian dapat ditarik kesimpulan bahwa e-learning dapat dihadirkan dengan mengetahui terlebih dahulu kebutuhan siswa untuk mengurangi kejenuhan dan persepsi dalam penggunaan platform dan aplikasi, kemudian kegiatan e-learning yang digemari berupa papan tulis online, serta model pembelajaran STAD dan PBL yang dimanfaatkan dalam pelaksanaan e-learning untuk meningkatakan kemampuan bahasa.

\section{SIMPULAN}

penurunan kualitas kognisi, keterampilan vokasi dan sosial yang dimiliki peserta didik saat ini benar-benar terikat serta tujuan pembelajaran menjadi luas, karena pendidik yang berperan penting adalah orangtua. Learning Loss merupakan salah satu aktivitas sosial yang muncul berkaitan dengan kemampuan peserta didik dan fasilitas pembelajaran e-learning. Pemetaan dalam bidang kurikulum juga menjadi perhatian khusus dalam mengkonsep tujuan mempelajari materi dan keunggulannya di masa yang akan datang, sehingga perlu adanya mitigasi lebih lanjut Learning Loss dan Deeper Learning sehingga peserta didik selaras dan sejalan dengan perkembangan abad 21 dan society 5.0 .

\section{UCAPAN TERIMA KASIH}

Penulis ucapkan terimakasih kepada Lembaga Penelitian dan Pengabdian masyarakat yang telah mensupport melalui pendanaan DIPA 2021 dan tidak lupa pula kepada Fakultas Keguruan dan Ilmu Pendidikan Universitas Borneo Tarakan dalam memotivasi tridharma perguruan tinggi pada homebase masing-masing jurusan.

\section{DAFTAR RUJUKAN}

Abbad, M. M., Morris, D., \& de Nahlik, C. (2009).Looking under the Bonnet: Factors Affecting Student Adoption of E-Learning Systems in Jordan.The International Review of Research in Open and Distance Learning.

Abbasi, S., Ayoob, T., Malik, A., \& ... (2020).Perceptions of students regarding Elearning during Covid-19 at a private medical college.In Pakistan Journal of Medical ncbi.nlm.nih.gov. https://www.ncbi.nlm.nih.gov/pmc/articles/pmc7306963/

Aboagye, E., Yawson, J. A., \& Appiah, K. N. (2021). COVID-19 and E-learning: The challenges of students in tertiary institutions. Social Education Research. https://ojs.wiserpub.com/index.php/SER/article/view/422

Al-Fraihat, D., Joy, M., \& Sinclair, J. (2020). Evaluating E-learning systems success: An empirical study. Computers in Human Behavior. 
https://www.sciencedirect.com/science/article/pii/S0747563219302912

Algahtani, A.F. (2011). Evaluating the Effectiveness of the E-learning Experience in Some Universities in Saudi Arabia from Male Students' Perceptions, Thesis, Durham University

Almosa, A. \& Almubarak, A. (2005).E-learning Foundations and Applications, Saudi Arabia: Riyadh.

Angrist, N., Barros, A. de, Bhula, R., Chakera, S., \& ... (2021). ... back better to avert a learning catastrophe: Estimating learning loss from COVID-19 school shutdowns in Africa and facilitating short-term and long-term learning .... International Journal of https://www.sciencedirect.com/science/article/pii/S073805932100050X

Angrist, N., Bergman, P., Brewster, C., \& ... (2020).Stemming learning loss during the pandemic: A rapid randomized trial of a low-tech intervention in Botswana.Available at SSRN ....https://papers.ssrn.com/sol3/papers.cfm?abstract_id=3678245

Arkorful, V., \& Abaidoo, N. (2015).The role of e-learning, advantages and disadvantages of its adoption in higher education.International Journal of Instructional Technology and Distance Learning, 12(1), 29-42.

Aziz, R. C., Hashim, N., Omar, R. N. R., Yusoff, A. M., \& ... (2019). Teaching and Learning in Higher Education: E-Learning as a Tool. In ... Journal of Innovative .... researchgate.net. https://www.researchgate.net/profile/AbdullahMuhamed-

Yusoff/publication/339352886_Teaching_and_Learning_in_Higher_Education_ E-Learning_as_a_Tool/links/5e4cfb78299bf1cdb9358637/Teaching-andLearning-in-Higher-Education-E-Learning-as-a-Tool.pdf

Almaiah, M. A., Al-Khasawneh, A., \& Althunibat, A. (2020). Exploring the critical challenges and factors influencing the E-learning system usage during COVID-19 pandemic. In Education and Information .... Springer. https://doi.org/10.1007/s10639-020-10219-y

Alqahtani, A. Y., \& Rajkhan, A. A. (2020). E-learning critical success factors during the covid-19 pandemic: A comprehensive analysis of e-learning managerial perspectives. Education Sciences. https://www.mdpi.com/803244

Bakle, B. R. (2010). Summer learning loss: The influence of summer school programs on student achievement in language usage, math, and reading. search.proquest.com.

https://search.proquest.com/openview/0af37924c373802ce0c9adb25bdbd03b/1?p q-origsite $=$ gscholar $\& \mathrm{cbl}=18750$

Bielinski, J., Brown, R., \& Wagner, K. (2020). COVID slide: Research on learning loss \& recommendations to close the gap. In Illuminate Education. fastbridge.org. https://www.fastbridge.org/wp-content/uploads/2020/09/covid-19-slidewhitepaper.pdf

Blaskó, Z., Costa, P. da, \& Schnepf, S. V. (2021). Learning loss and educational inequalities in europe: Mapping the potential consequences of the COVID-19 crisis.

papers.ssrn.com.

https://papers.ssrn.com/sol3/papers.cfm?abstract_id=3833230 
Bowers, L. M., \& Schwarz, I. (2018). Preventing summer learning loss: Results of a summer literacy program for students from low-SES homes. Reading \& Writing Quarterly. https://doi.org/10.1080/10573569.2017.1344943

Burdman, P. (1998). Cyber U. Anaheim (California) Orange County Register, September 13, sec. 1

Dorn, E., Hancock, B., Sarakatsannis, J., \& ... (2020). COVID-19 and learning lossdisparities grow and students need help. In McKinsey \& Company .... strumpfassociates.com. https://www.strumpfassociates.com/demo/wpcontent/uploads/2021/01/COVID-19-and-learning-loss-disparities-grow-andstudents-need-help-V2-1.pdf

Dowling, C., Godfrey, J. M. \& Gyles N. (2003). Do Hybrid Flexible Delivery Teaching Methods Improve Accounting Students' Learning Outcomes. Accounting Education:An International Journal, 12 (4), 373-391.

Dublin, L. (2003). If you only look under the street lamps...... Or nine e-Learning Myths.The eLearning developers journal.http://www.eLearningguild.com

Ebner, M., Schön, S., Braun, C., Ebner, M., Grigoriadis, Y., \& ... (2020). COVID-19 epidemic as E-learning boost? Chronological development and effects at an Austrian university against the background of the concept of "E-Learning .... Future Internet. https://www.mdpi.com/725974

Engzella, P., Frey, A., \& Verhagena, M. D. (2021). Learning loss due to school closures during the COVID-19 pandemic. In PNAS. scholar.archive.org. https://scholar.archive.org/work/6mkv5ze4bbacla3i2xerbxo6om/access/wayback/ https://www.pnas.org/content/pnas/118/17/e2022376118.full.pdf

Fontana, A. \& Frey, J.H. (1994) Interviewing, in N.K. Denzin \& Y.S. Lincoln (Eds) The Handbook of Qualitative Research. Thousand Oaks: Sage.

Hooker, J., \& Denker, K. (2014). The Learning Loss Scale as an assessment tool: An empirical examination of convergent validity with performative measures. Communication Teacher. https://doi.org/10.1080/17404622.2013.865765

Huang, Y., Wang, Y., Tai, Y., Liu, X., \& ... (2020). Curricularface: adaptive curriculum learning loss for deep face recognition. Proceedings of the .... http://openaccess.thecvf.com/content_CVPR_2020/html/Huang_CurricularFace_ Adaptive_Curriculum_Learning_Loss_for_Deep_Face_Recognition_CVPR_202 0_paper.html

Kaffenberger, M. (2021). Modelling the long-run learning impact of the Covid-19 learning shock: Actions to (more than) mitigate loss. In International Journal of Educational Development. Elsevier. https://www.sciencedirect.com/science/article/pii/S0738059320304855

Kraft, M. A., \& Monti-Nussbaum, M. (2017). Can schools enable parents to prevent summer learning loss? A text-messaging field experiment to promote literacy skills. The ANNALS of the .... https://doi.org/10.1177/0002716217732009

Kementerian Pendidikan Dan Kebudayaan. (2016). Pedoman Guru Pembelajar. Kemendikbud. Jakarta

Kemmis, S., \& McTaggart, R. (1988). The action research planner. Victoria. Australia: Deakin University.

Keller, C. \& Cernerud, L. (2002).Students' perception of e-learning in university education. Learning, Media and Technology, 27(1), 55-67.

Kuhfeld, M. (2019). Surprising new evidence on summer learning loss. Phi Delta Kappan. https://doi.org/10.1177/0031721719871560 
Kuhfield, M., \& Tarasawa, B. (2020). The COVID-19 Slide: What Summer Learning Loss Can Tell Us about the Potential Impact of School Closures on Student Academic Achievement. Brief. NWEA. https://eric.ed.gov/?id=ED609141.

LaRose, R., Gregg, J., \& Eastin, M. (1998). Audio graphic tele-courses for the Web: An experiment. Journal of Computer Mediated Communications, 4(2).

Lincoln, Y.S. \& Guba, E.G. (1985) Naturalistic Inquiry. Beverly Hills: Sage.

Maltz, L., Deblois, P. \& The Educause Current Issues Committee. (2005). Top Ten IT Issues. EDUCAUSE Review, 40 (1), 15-28.

Mayes, T. (2002) Pedagogy, Lifelong Learning and ICT: A Discussion Paper for the Scottish Forum on Lifelong Learning.Journal of Instructional Science and Technology 5(1)

McEachin, A., \& Atteberry, A. (2017). The impact of summer learning loss on measures of school performance. Education Finance and Policy. https://direct.mit.edu/edfp/article-abstract/12/4/468/10289

McNeish, D., \& Dumas, D. (2021). A seasonal dynamic measurement model for summer learning loss. Journal of the Royal Statistical Society .... https://doi.org/10.1111/rssa.12634

Medela, A., \& Picon, A. (2019). Constellation loss: Improving the efficiency of deep metric learning loss functions for optimal embedding. ArXiv Preprint ArXiv:1905.10675. https://arxiv.org/abs/1905.10675

Mayer, R. E. (2020). Searching for the role of emotions in e-learning. Learning and Instruction.

https://www.sciencedirect.com/science/article/pii/S095947521930324X

Menard, J., \& Wilson, A. M. (2014). Summer learning loss among elementary school children with reading disabilities. Exceptionality Education International. https://ojs.lib.uwo.ca/index.php/eei/article/view/7705

Miller, R. (2012). ... Absence as a Leading Indicator of Student Achievement: New National Data Offer Opportunity to Examine Cost of Teacher Absence Relative to Learning Loss. Center for American Progress. https://eric.ed.gov/?id=ED536902

Nursalam, N., \& Nursalam, N. (2021). PEMANFAATAN FASILITAS BELAJAR DI SEKOLAH DAN PENGARUHNYA TERHADAP HASIL BELAJAR IPS SISWA KELAS VIII MTS DARUL FALAH CERMEE BONDOWOSO SEMESTER GENAP. JURNAL PENDIDIKAN DAN KEWIRAUSAHAAN, 1(2), 74-81.

Retrieved

from https://journalstkippgrisitubondo.ac.id/index.php/PKWU/article/view/197

Pham, L., Limbu, Y. B., Bui, T. K., Nguyen, H. T., \& ... (2019). Does e-learning service quality influence e-learning student satisfaction and loyalty? Evidence from Vietnam. In International Journal of .... Springer. https://doi.org/10.1186/s41239019-0136-3

Oblinger, D. G., \& Hawkins, B. L. (2005). The myth about E-learning. Educause review

OECD (2005).E-learning in tertiary education [Online]. http://www.cumex.org. Diakses 3 Mei 2020

Orlando, J., \& Attard, C. (2016). Digital natives come of age: The reality of today's early career teachers using mobile devices to teach mathematics. Mathematics Education Research Journal, 28(1), 107-121.

Patton, K. L. S., \& Reschly, A. L. (2013). Using curriculum-based measurement to examine summer learning loss. Psychology in the Schools. https://doi.org/10.1002/pits.21704. 
Rossi.P.G. (2009). Learning environment with artificial intelligence elements. Journal of e-learning and knowledge society, 5(1), 67-75.

Sabates, R., Carter, E., \& Stern, J. M. B. (2021). Using educational transitions to estimate learning loss due to COVID-19 school closures: The case of Complementary Basic Education in Ghana. International Journal of Educational https://www.sciencedirect.com/science/article/pii/S0738059321000304

Shinwell, J., \& Defeyter, M. A. (2017). Investigation of summer learning loss in the UK-Implications for holiday club provision. In Frontiers in Public Health. frontiersin.org. https://www.frontiersin.org/articles/10.3389/fpubh.2017.00270/full

Surat Edaran Kemendikbud Nomor 4 Tahun 2020 tentang Pelaksanaan Kebijakan Pendidikan dalam Masa Darurat Penyebaran Coronavirus Disease (Covid-19)

Syakur, A., \& Sabat, Y. (2020). The Effectiveness of Coopertative Learning (STAD and PBL type) on E-learning Sustainable Development in Higher Education. Journal of Development Research. http://www.journal.unublitar.ac.id/jdr/index.php/jdr/article/view/98

Todd, A., \& Romine, W. (2018). The Learning Loss Effect in Genetics: What Ideas Do Students Retain or Lose after Instruction? CBE-Life Sciences Education. https://doi.org/10.1187/cbe.16-10-0310

Travis, R., Gann, E., Crooke, A. H. D., \& ... (2019). Hip Hop, empowerment, and therapeutic beat-making: Potential solutions for summer learning loss, depression, and anxiety in youth. Journal of Human ... https://doi.org/10.1080/10911359.2019.1607646

Turner, K. L., Hughes, M., \& Presland, K. (2020). Learning loss, a potential challenge for transition to undergraduate study following COVID19 school disruption. Journal of Chemical .... https://doi.org/10.1021/acs.jchemed.0c00705

Wu, E. H. K., Lin, C. H., Ou, Y. Y., Liu, C. Z., Wang, W. K., \& ... (2020). Advantages and constraints of a hybrid model K-12 e-learning assistant chatbot. IEEE .... https://ieeexplore.ieee.org/abstract/document/9069183/

$\mathrm{Xu}, \mathrm{Z}$., Hsu, Y. C., \& Huang, J. (2017). Learning loss for knowledge distillation with conditional adversarial networks. openreview.net. https://openreview.net/forum?id=L26YbuvdqV9

Yoo, D., \& Kweon, I. S. (2019). Learning loss for active learning. ... of the IEEE/CVF Conference

on http://openaccess.thecvf.com/content_CVPR_2019/html/Yoo_Learning_Loss_fo r_Active_Learning_CVPR_2019_paper.html

Young, J. R. (1997). Rethinking the Role of the Professor in an Age of High-Tech Tools. The Chronicle of Higher Education, 44 (6). 